УДК 22.06:224.5

DOI 10.35423/2078-8142.2021.1.2.09

I. I. Куриляк, аспірант богослов'я факультету філософії та суспільствознавства, кафедра богослов'я та релігієзнавства, Начіональний педагогічний університет імені М. П. Драгоманова, м. Київ, Украӥна e-mail: igor.kuryliak@gmail.com ORCID: https://orcid.org/0000-0003-3955-1929

\title{
СПЕЦИФІКА ІНТЕРПРЕТАЦЇ̈ ЄФРЕМА СИРИНА ЕСХАТОЛОГІЧНИХ ОБРАЗІВ У ДАН. 7
}

У статті досліджено особливості інтерпретаиії Єфрема Сирина сьомого розділу апокаліптичної книги пророка Даниїла. 3'ясовано, шо Сфрем інтерпретує чотири звірі як Вавилон, Мідію, Персію і Грецію. Визначено, щзо таке тлумачення відрізняється від традиційного тлумачення ранньохристиянських письменників, які вважали, щео чотири царства - цее Вавилон, Мідо-Персія, Греція $i$ Рим. Автор статті наводить трунтовні аргументи, які доводять, щзо другим ияарством є Мідо-Персія, третім иарством є Греція, а четвертим - Рим. Встановлено, щз інтерпретація Сфрема не знаходить біблійної основи і тому уступає традиційному тлумаченню. Проведений аналіз засвідчує, щяо інтерпретація Єфрема Дан. 7 має герменевтичні принципи сучасної претеристської школи тлумачення. 3'ясовано, щио теолог інтерпретував образ малого рогу в Дан. 7 як Антіоха Епіфана. Автор статті висвітлює вісім ідентифікаиійних особливостей малого рогу, які зображені в сьомому розділі. Досліджено, що, на думку представників істористської школи, малий ріг символізує папство. Подальший розгляд названої наукової проблематики вбачаємо у глибокому екзегетичному аналізі есхатологічних образів у Дан. 7.

Ключові слова: Книга Даниїла, Сфрем Сирин, Дан. 7, інтерпретація, апокаліптичний, пророк Даниїл, герменевтика. 
Апокаліптична книга пророка Даниїла має виразний есхатологічний богословський напрям. Яскраві образи цієї книги приваблювали багатьох ранньохристиянських теологів, які намагалися осмислити їхне значення та представити вірну інтерпретацію. У результаті з'явилася велика кількість різноманітних інтерпретацій, які часто-густо суперечать одна одній. Серед ранньохристиянських дослідників, які тлумачили пророцтва книги Даниїла, можна згадати одного з найважливіших представників сирійської поезії - Сфрема Сирина (306-373 р. н.е.). Сфрем посідає одне 3 перших місць серед екзегетів східної церкви, а його коментарі до книг Святого Письма є важливими для дослідження історії інтерпретації. Теолог написав коментар до книги Даниїла, де представив своє богословське тлумачення. Серед есхатологічних пророцтв книги Даниїла визначне місце займає розділ 7, де описане перше видіння пророка. Богослов Жак Дукан вважає цей розділ центром книги [3, с. 141]. Інтерпретація Єфрема Дан. 7 відрізняється від традиційного тлумачення ранньохристиянських письменників [20, с. 220]. Тому важливе місце Єфрема Сирина серед сирійських теологів, центральне місце сьомого розділу в книзі Даниїла і специфіка тлумачення теолога зумовлює актуальність дослідження інтерпретації Єфрема Дан. 7.

Учений Філ Бота здійснив грунтовний аналіз інтерпретації Єфрема Сирина в книзі «Історія тлумачення Даниїла в юдаїзмі, християнстві та ісламі» [9, с. 99-122]. Аналіз інтерпретації книги Даниїла Сфрема Сирина також зробив богослов ЛеРой Фрум у своєму колосальному дослідженні «Пророча віра наших батьків. Том 1» [11, с. 405]. Фрум у загальному представляє погляди Єфрема стосовно антихриста [11, с. 405-406]. Також учений Вільям Шеа у книзі «Симпозіум на Даниїла» коротко висвітлює інтерпретацію Єфрема Сирина [14, с. 309]. Шеа доходить висновку, що теолог «вважав, що більшість пророчих знаків були виконані» $[14$, c. 309]. Ще можна згадати богослова Ігоря Безсонова, який у своїй праці «Пророцтва книги Даниїла: походження, історія екзегетики, тлумачення» досліджує історію екзегетики пророчої книги, аналізує різні тлумачення, зокрема й інтерпретацію Єфрема [1]. До того ж, можна ще згадати таких дослідників, як Р. Ендрес [9, с. 150-151], Чарльз Каненгіссер [14, с. 320-323] та ін. 
Незважаючи на ці праці, варто зауважити, що у них відсутнє комплексне дослідження тлумачення Єфрема Сирина есхатологічних пророцтв Дан. 7.

Тому мета цієї статті - розкрити специфіку інтерпретації Єфрема Сирина Дан. 7. Для виконання цієї мети були поставлені такі завдання: 1) висвітлити інтерпретацію Дан. 7 Сфрема Сирина; 2) проаналізувати герменевтичні методи екзегета; 3) здійснити богословський аналіз його інтерпретації.

Єфрем Сирин інтерпретує перші символи сьомого розділу у такий спосіб: «Море $\epsilon$ світ; чотири вітри неба - правителі чотирьох царств; і чотири звіра, що виходять 3 моря, - це чотири царі різні між собою могутністю» [5, с. 64-65]. Інтерпретація символу моря у Дан. 7 не викликає труднощів і тому більшість дослідників погоджуються, що символ моря, яке хвилюється, - це «частий біблійний образ для опису народів світу (Ic. 17:12-13; 57:20; 60:5; Є3. 26:3; Об'явл. 13:1; 17:15)» [6, с. 876; 19, с. 249; 21, c. 151; 2, с. 72]. Богослов Джон МакАртур відзначає, що у пророцтві мається на увазі Середземне море, яке є символом націй і народів [15, с. 71]. Наведені вище біблійні тексти справді підтверджують, що образ моря як символ народів був добре відомий для євреїв. Подібно до того, як море часто штормить, так і народи світу перебувають у конфліктах та війнах [6, с. 876].

Згідно $з$ наведеною цитатою бачимо, що Єфрем тлумачить чотири вітри як правителів чотирьох царств. Богослов Жак Дукан стверджує, що під чотирма вітрами «маються на увазі чотири сторони світу (пор. Зах. 6:5)» [3, с. 142]. Здравко Стефанович додає: «образно це число виражає ідею повноти або тотальності щодо простору (пор. Бут. 2:10)» [19, с. 249]. Також чотири вітри в Біблії означають «шторми війни та завоювання (Єр. 25:31-33; 49:36, 37; Зах. 7:14; Об'явл. 7:1)» [16, с. 62]. Деякі дослідники вбачають у цих символах міфологічний підтекст [12, с. 160; 7, с. 947]. Якщо інтерпретувати чотири вітри як політичні конфлікти і війни, то правителі царств, які беруть участь у політичній діяльності, цілком можуть відповідати цьому символу. Отже, інтерпретація Єфрема Сирина образів «моря» та «чотирьох вітрів» (Дан. 7:2) достатньо обгрунтована і знаходить біблійну основу. 
Інтерпретуючи першого звіра Сфрем Сирин пише: «це є царство Вавилонське. I це видіння Даниїла схоже з тим видінням, яке Даниїл витлумачив Царю Навуходоносору. Значення видінь одне: Вавилонське царство, представлене там в образі золота, яке краще всякої речовини, тут представляється в образі сильного лева і легкокрилого орла» [5, с. 65]. 3 огляду на сказане бачимо, що Єфрем тлумачив 2 і 7 розділи книги Даниїла як паралельні пророцтва. Такого підходу дотримуються майже всі дослідники, зокрема серед ранньохристиянських письменників можна вирізнити Іполита Римського [4, с. 145-168], Єроніма [20, с. 220-225], Феодорита Кирського [13, с. 177-183] та ін.

Ідентифікація образу лева $з$ крилами (Дан. 7:4) не спричиняє значних труднощів, оскільки цей символ часто використовувався у мистецтві Вавилонської імперії [3, с. 143]. Також сам цар Навуходоносор у Біблії порівнюється з левом та орлом (Єр. 4:7, 13; 50:17, 44) [3, с. 143]. Крім цього образ лева з орлиними крилами у стародавньому світі був символом краси, сили, величі і швидкості $[19$, c. 258]. Як і перше царство боввана у другому розділі було представлено найдорожчим металом у боввані - золотом, так і перше царство у сьомому розділі представлено найвеличнішим звіром і птахом - левом 3 орлиними крилами [3, с. 144]. Важливо також звернути увагу на слова Даниїла до Навуходоносора: «Ти, царю, цар над царями, якому Небесний Бог дав царство, владу й міць та славу. I скрізь, де мешкають людські сини, польова звірина та птаство небесне, Він дав їх у твою руку, та вчинив тебе пануючим над усіма ними. Ти голова, що з золота» (Дан. 7:37, 38). Отже, можна 3 впевненістю сказати, що інтерпретація Сфрема Сириного символу «лева 3 крилами» як Вавилонської імперії має грунтовну біблійну основу.

Про другого звіра в Дан. 7 Єфрем відзначає: «Цим зображується царство Дарія, царя Мідійського. Бо як в боввані, якого бачив Навуходоносор, Мідійське царство було представлено образом срібла, яке менш цінне, ніж золото, так тут представлено воно в образі ведмедя, який не такий повороткий, як лев» [5, с. 65]. Відповідно до інтерпретації Єфрема вислів «і був поставлений на одному боці» (Дан. 7:5) означає, що на відміну від свого попередника Навуходоносора, який царював над усією землею, Дарій царюва- 
тиме тільки у своєму царстві [5, с. 65]. Три ребра, які тримав ведмідь у своїй пащі між зубами, теолог тлумачить як три народи: мідян, персів і халдеїв [5, с. 65]. А повеління ведмедю «Уставай, їж багато м'яса!» (Дан. 7:5), на думку автора, означає царство вавилонян, яке було спустошене і немов пожерте мідянами [5, с. 65].

Єфрем Сирин інтерпретує третього звіра (пантеру) як Перську імперію [5, с. 65]. Автор знов проводить паралелі з бовваном і стверджує, що подібно до того, як мідь боввана символізує Персію, так і пантера представляє те саме царство [5, с. 65]. Теолог вважає, що чотири крила і чотири голови третього звіра означають, «що царство це поширить своє панування на чотири небесні вітри» [5, с. 65]. Слова «і була йому дана влада» (Дан. 7:6) Єфрем інтерпретує як поневолення цим царством інших народів [5, с. 66].

Якщо в інтерпретації першого звіра у дослідників майже не виникає розбіжностей, то від другого звіра тлумачення починають різнитися [21, с. 154]. Серед ранньохристиянських богословів існували два основні напрями інтерпретації чотирьох царств: 1) Вавилон, Мідія, Персія і Греція (Сфрем Сирин, Ішодад); 2) Вавилон, Мідо-Персія, Греція і Рим (Іполит Римський, Кирило Єрусалимський, Іван Золотоустий, Феодорит Кирський, Єронім); $[20$, с. 220]. Інтерпретація чотирьох царства як Вавилона, МідоПерсії, Греції і Риму вважається традиційною серед ранніх богословів християнської Церкви [20, с. 226]. Сьогодні ліберальні теологи та критики здебільшого дотримуються позиції Єфрема Сирина, а консервативні богослови інтерпретують друге царство як Мiдо-Персію [5, с. 154-155]. Аналіз засвідчує, що інтерпретація Сфрема чотирьох царств має герменевтику сучасної претеристської школи тлумачення.

Інтерпретація Єфрема другого звіра виключно як Мідію, а третього як Персію не знаходить підтвердження як у самій книзі Даниїла, так і в історичних даних [21, с. 147-159]. По-перше, в книзі Даниїла мідяни та перси представлені як одне царство (Дан. 5:28; 6:8, 12, 15; 8:20). Богослов Валвурд пише: «у розділі 6 Даниїла об'єднане царство мідян та персів неодноразово згадується, як у віршах 8, 12 і 15. Ці посилання самі по собі повинні змусити замовчати критика, який хоче приписати Даниїлу помилкове i 
неісторичне царство Мідії. Історія Даниїла відповідає історії, тоді як точка зору критиків - ні» [21, с. 155]. По-друге, деталі пророчих символів допомагають 3 точністю ототожнити друге і третє царство як Мідо-Персію і Грецію. Наприклад, ведмідь зображений як той, хто «був поставлений на одному боці» (Дан. 7:5), що може вказувати на відносини між мідянами та персами - один народ буде домінувати над іншим [21, с. 156]. У 8 розділі царство мідян та персів представлено в образі барана 3 двома рогами: «а обидва ці роги високі, і один вищий від другого, а той вищий виріс наостанку» (Дан. 8:3). В історії ми знаходимо підтвердження цього пророцтва [3, с. 145]. Спочатку мідійці домінували над персами, але потім верховна влада в часи Кіра переходить персам [19, с. 321]. Також три ребра, які тримав ведмідь у зубах, вказують на завоювання Мідо-Персії Вавилону, Лідії і Сгипту [2, с. 74].

Третє царство зображене в образі пантери або рисі з чотирма головами і крилами (Дан. 7:6). Дослідники стверджують, що образ швидкого і спритного звіра з орлиними крилами було обрано 3 метою представити стрімкість, з якою Александр Македонський завоював Мідо-Персію [2, с. 74]. Також чотири голови вказують на чотири основні частини, на які розділилася Грецька імперія: Селевкіди контролювали Сирію і Схід аж до Індії; західна Мала Азія і Фракія стали належати Лізімаху; Птолемей став царем Сгипту; i Кассандр був визнаний як правитель Греції [8, с. 1031]. Образ козла у Дан. 8, який є паралельний образу пантері у Дан. 7, зображений $з$ чотирма рогами, що також вказує на розділення Греції: «А козел, той волохатий, це цар Греції, а той великий ріг, що між очима його, це перший цар. А той зламаний ріг, і що стали на його місці чотири, це чотири царства постануть із цього народу, але вже не в його силі» (Дан. 8:21, 22). Отже, наведені вище аргументи дають підставу стверджувати, що другий звір символізує МідоПерсію, а третій - Грецію. Тому, виходячи 3 вищевикладеного, 3 прикрістю констатуємо, що інтерпретація Єфрема Сирина стосовно інтерпретації царств у Дан. 7 не відповідає біблійному контексту та уступає традиційному тлумаченні ранньохристиянських теологів.

Про четвертого звіра Сфрем Сирин пише: «Це - Александр, цар Грецький, якого пророк і там представляє в образі твердого за- 
ліза, і про який тут говорить, що у нього великі залізні зуби. I ці зуби означають сильні воїнства, з якими Олександр підкорив всіх царів» [5, с. 66]. Десять рогів четвертого звіра автор тлумачить як десять царів, які повстали після Александра [5, с. 66]. Про малий ріг, який з'являється між 10 рогами (Дан. 7:8) Єфрем говорить: «Це - гонитель Антіох, який виник і посилився із середовища десяти царів» [5, с. 66]. Дії малого рогу в Дан. 7 теолог інтерпретує в контексті діяльності царя Антіоха IV Епіфана (215-164 р. до н.е.) [5, с. 66]. На думку Єфрема, слова «Я бачив, аж ось поставили престоли» (Дан. 7:9) означають суд над греками, який передбачає майбутній останній суд, коли Христос судитиме живих і мертвих [5, с. 66]. Текст Дан. 7:13 письменник інтерпретує як кульмінацію пророцтв - Перший прихід Ісуса Христа [5, с. 67].

Як ми вже відзначали, Єфрем інтерпретує чотири царства відмінно від традиційного тлумачення отців церкви. Оскільки він інтерпретує друге царство як Мідію, а третє - як Персію, то наслідком такого тлумачення $є$ ідентифікація четвертого звіра як Греції. Зауважимо, що така інтерпретація не зовсім вірна, оскільки аналіз контексту дає можливість зробити висновок, що четвертим звіром в Дан. 7 є Рим, а не Греція.

По-перше, згідно з історичними даними, після Грецької імперії до влади прийшла Римська імперія [2, с. 74-75; 21, с. 159163]. Вище наведений аналіз засвідчив, що третім звіром в Дан. 7 є Греція, а не Персія, як стверджує Сфрем Сирин. Тому з цього випливає, що четвертий звір вказує на царство, яке буде слідувати за Грецією. Сьогодні ні в кого не виникає сумніву, що це Римська імперія [18, с. 132]. Згідно з пророцтвом Дан. 8, Грецька імперія мала розділитися на чотири частини (Дан. 8:21, 22). Відповідно до історичних даних, усі ці чотири царства були завойовані Римською імперією [18, с. 132]. Богослов Вільям Шеа відзначає: «Рим першим підкорив Грецію. Тоді йому заповів Малу Азію цар Пергама, у якого не було потомства чоловічої статі. Потім Сирія разом з Юдеєю впала перед Помпеєм і його легіонами. Нарешті, Сгипет, останній 3 чотирьох, упав перед Римом. Таким чином, Рим завершив завоювання басейну східного Середземномор'я» [18, с. 133]. 
По-друге, Новий Завіт вказує на те, що четверте царство - це Рим [8, с. 1031]. В останні дні свого життя, пророкуючи про майбутне, Ісус сказав: «Тож, коли ви побачите ту гидоту спустошення, що про неї звіщав був пророк Даниїл, на місці святому, хто читає, нехай розуміє, тоді ті, хто в Юдеї, нехай в гори втікають» (Мт. 24:15, 16). У цих текстах Христос має на увазі деякі пророцтва 3 книги Даниїла (Дан. 9:24-27), що говорять про зруйнування римлянами Срусалиму, яке відбулося в 70 році н.е. Дослідники стверджують, що ці слова Ісуса підтримують ідею, що саме Рим $є$ четвертим царством [21, с. 161]. Богослов Джон Валвурд пише: «Ймовірно, найбільш вирішальним аргументом на користь інтерпретації четвертої імперії як Римської є факт, згаданий в попередньому обговоренні, що Новий Завіт, здається, слідує цій інтерпретації. Христос, кажучи про “гидоту спустошення” (Мт. 24:15), ясно описує осквернення храму, про яке тут пророкував як про майбутню подію» [21, с. 161].

Крім цього, книга Об'явлення використовує символи з книги Даниїла і застосовує їх як до Римської імперії, так і до всієї християнської ери аж до Другого приходу Христа. Наприклад, звір 3 моря має характеристики малого рогу в Дан. 7 і застосовується до майбутнього, на думку апостола Івана (Об'явл. 13). Також в Об'явл. 12 Іван застосовує пророчий період «час, часи і півчасу» 3 Дан. 7:25 до майбутнього переслідування Божої церкви в християнську епоху (що відбувалося в середні віки вже після розділення Римської імперії). Валвурд зазначає: «У Новому Завіті також, здається, використовується символіка Даниїла в книзі Об'явлення, представлена як майбутнє навіть після зруйнування храму» [21, с. 161]. Отже, наведені приклади підтверджують, що четверте царство - це Рим.

По-третє, характеристики четвертого звіра більше відповідають Римській імперії, ніж Грецькій. Про четвертого звіра написано: «страшний і грізний, та надмірно міцний, і в нього великі залізні зуби. Він жер та торощив, а решту ногами своїми топтав» (Дан. 7:7). Римська імперія славилася своєю жорстокістю та нищівною поведінкою по відношенню ворогів [17, с. 823-826]. Вона проіснувала більш за всі інші імперій, управляючи світом близько шести століть [2, с. 75]. Богослов Ростислав Волкославський пише: 
«Нищівна міць римських легіонів, одягнених у залізні обладунки та спаяних залізною дисципліною, була тією силою, яка підкорила своєму пануванню величезні населені простори від Свфрату на сході до Іспанії на заході, від Ефіопії на півдні до Шотландії на півночі» [2, с. 75].

Також у восьмому розділі книги Даниїла стверджується, що Грецька імперія мала розділитися на чотири основні частини, що і відбулося, згідно з історією (більшість дослідників вказують на таких діадохів: Селевк, Лізімах, Птолемей і Кассандр) [17, с. 824825]. У Дан. 7 про ці чотири частини можуть вказувати чотири голови пантери (Дан. 7:6). На відміну від Грецької імперії, четвертий звір розділяється на 10 частин (Дан. 7:7, 24). У Дан. 2 це зображено 10 пальцями боввана, що були частиною 3 глини, а частиною - i3 заліза (Дан. 2:33, 41-43). Історія підтверджує, що Римська імперія розділилася на 10 частин [3, с. 148; 17, с. 826]. Жак Дукан зауважує: «У працях істориків, які перераховують ці народи, зустрічаються невеликі розбіжності; але більшість істориків називають такі народи: франки, бургунди, алеманни, вандали, свеви, вестготи, сакси, остготи, ламбарди і герули» [3, с. 148]. Отже, наведені аргументи доводять, що четвертий звір - це Рим. Тому інтерпретація Єфрема четвертого звіра як Греції суперечить біблійному контексту сьомого розділу і всієї книги Даниїла.

Варто також звернути увагу на інтерпретацію малого рогу в Дан. 7. Цей образ викликав велику цікавість у Даниїла (Дан. 7:19, 20), який приділяє його опису значну частину тексту [3, с. 148]. Якщо четвертим звіром є Римська імперія, значить малий ріг у Дан. 7 не може в будь-якому випадку символізувати Антіоха. Оскільки малий ріг походить від четвертого звіра (Дан. 7), то 3 цього випливає, що він має з'явитися з Римської імперії, або точніше після іï розділення на 10 частин. Іполит Римський писав: «після цього, Римського царства не виникне ще жодного іншого царства, але що 3 нього, втім, виростуть десять рогів, і посередині їх з'явиться один малий (ріг), і тоді три 3 числа перших будуть викорінені» [4, с. 149].

Здравко Стефанович представляє вісім ідентифікаційних характеристик малого рогу $[19$, с. 281]. Перша характеристика засві- 
дчує, що він виникає $з$ четвертого звіра (Дан. 8, 24) [19, с. 281]. Згідно 3 другою характеристикою, малий ріг з'являється після десяти інших рогів: «десять рогів визначають, що 3 того царства встане десять царів, а по них встане інший» (Дан. 7:24) [19, с. 281]. Третя характеристика - малий ріг спочатку зображений маленьким, але потім він стає більшим від усіх інших рогів: «а вид його більший від його друзів» (Дан. 7:20) [19, с. 281]. Четверта - малий ріг викорінює три роги 3 десяти (Дан. 7:8, 24) [19, с. 281]. Згідно 3 п’ятою відмінною рисою, малий ріг мав «очі, як очі людські, і уста, що говорили про великі речі» і «він буде говорити слова проти Всевишнього» (Дан. 7:8, 25) [19, с. 281]. Шоста своєрідність - буде пригноблювати «святих Всевишнього» (Дан. 7:25) [19, с. 281]. Відповідно до сьомої особливості малий ріг мав намір змінити час і закони (Дан. 7:25) [19, с. 281]. Остання восьма характеристика - це проміжок часу, протягом якого діятиме малий ріг: «один час, часи i половина часу» (Дан. 7:25) [19, с. 281]. На підставі цих характеристик представники істористської школи інтерпретують малий ріг у Дан. 7 як папство - Римо-католицьку церкву [3, с. 158; 16, с. 63; 19, c. 281]. Стефанович стверджує: «Тільки одна сутність справді відповідає всім восьми 3 цих ідентифікаційних знаків - християнська церква, яка стала відомою як “релігійно-політична", коли занепала Римська імперія» [19, с. 281]. На нашу думку, така інтерпретація цілком відповідає біблійному контексту і має сильні екзегетичні підстави.

Отже, у статті було розкрито специфіку інтерпретації Єфрема Сирина Дан. 7. Висвітлено, що теолог тлумачив апокаліптичні образи «море» (Дан. 7:2) як світ, а «чотири вітри неба» (Дан. 7:2) це правителі чотирьох царств. З'ясовано, що Єфрем тлумачив Дан. 2 і Дан. 7 як паралельні пророцтва, що передбачають той самий поступ історії нашої планети. Автор вважав, що перший звір у Дан. 7 означає Вавилонське царство. Досліджено, що така інтерпретація має біблійну основу і підтверджується безпосередньо словами пророка Даниїла (Дан. 2:37, 38). 3'ясовано, що другого звіра у Дан. 7 Єфрем інтерпретує як Мідійське царство. На думку теолога, третій звір символізував Перську імперію, а четвертий звір - це Греція. 
Висвітлено, що серед ранньохристиянських письменників існували два основні напрямки тлумачення чотирьох царств в Дан. 7: 1) Вавилон, Мідія, Персія і Греція; 2) Вавилон, Мідо-Персія, Греція i Рим. Аналіз засвідчив, що Єфрем належав до першого напряму. Представлено, що сьогодні ліберальні теологи та критики здебільшого дотримуються позиції Єфрема Сирина. 3'ясовано, що інтерпретація Єфрема чотирьох царств має герменевтику сучасної претеристської школи інтерпретації. Богословський аналіз дав можливість дійти висновку, що інтерпретація Єфрема Сирина чотирьох царств суперечить біблійному контексту і уступає традиційному тлумаченні цих символів. Представлені нами аргументи доводять, що чотири царства в Дан. 7 - це Вавилон, Мідо-Персія, Греція і Рим. Висвітлені ідентифікаційні характеристики малого рогу в Дан. 7 дають право вважати, що він символізує не Антіоха Епіфана, як про це стверджує Сфрем, а папство. Подальший розгляд зазначеної наукової проблематики вбачаємо у грунтовному екзегетичному дослідженні апокаліптичних образів у Дан. 7. Переконані, що це дасть можливість краще осягнути есхатологічні образи книги Даниїла та зрозуміти їхнє виконання в історичній площині.

\section{ЛIТЕРАТУРА}

1. Бессонов И. Пророчества книги Даниила: происхождение, история экзегетики, толкование. Санкт-Петербург : Алетейя, 2019. 553 с.

2. Волкославский Р. Тайны Апокалипсиса. Исторический комментарий на пророческие Книги Даниила и Откровение. Заокский : Источник жизни, 2008. 352 с.

3. Дукан Ж. Стенание Земли. Исследование Книги пророка Даниила. Заокский : Источник жизни, 1995. 320 с.

4. Ипполит Римский. О Христе и антихристе. Санкт-Петербург : Библиополис, 2008. 400 с.

5. Святой Ефрем Сирин. Творения. Том 6. Москва : Отчий дом, 1995. $485 \mathrm{c}$.

6. Уирсби У. Комментарий на Ветхий Завет. Том 2. Ездра - Малахия. Санкт-Петербург : Библия для всех, 2011. 1105 с.

7. Уолтон Д., Мэтьюз В., Чавалес М. Библейский культурноисторический комментарий. Часть 1: Ветхий Завет. Санкт-Петербург : Мирт, 2003. 1088 с. 
8. Andrews Bible Commentary (Old Testament). Berrien Springs : Andrews University Press, 2020. 1184 c.

9. Bracht K., Du toit D. Die Geschichte der Daniel-Auslegung in Judentum, Christentum und Islam (Beihefte Zur Zeitschrift Fur die Alttestamentliche Wissenschaft). Berlin, New York : Walter de Gruyter, 2007. 396 c.

10. Endresz R. Daniel: A Survey of Patristic Exegesis (p. 100-451). Phronema. 2016. Вип. 1. Т. 31. С. 123-152.

11. Froom L. Prophetic Faith of Our Fathers. The Historical Development of Prophetic Interpretation. Vol. 1. Washington : Review and Herald, 1950. $1006 \mathrm{c}$.

12. Goldingay J. Word Biblical Commentary, Vol. 30: Daniel. Dallas : Word, 2002. $416 \mathrm{c}$.

13. Hill R. Theodoret of Cyrus: Commentary on Daniel. Leiden, Boston : Brill, 2006. $367 \mathrm{c}$.

14. Holbrook F. Symposium on Daniel (Daniel \& Revelation Committee Series). Washington : Biblical Research Institute, 1986. $557 \mathrm{c}$.

15. MacArthur J. Daniel: God's Control Over Rulers and Nations (MacArthur Bible Studies). Nashville : Thomas Nelson, 2000. 144 c.

16. Pfandl G. Daniel: The Seer of Babylon. Hagerstown : Review \& Herald Publishing, 2004. $121 \mathrm{c}$.

17. Seventh-day Adventist Bible Commentary. Vol. 4. Washington: Review and Herald Publishing Association, 1977. 1184 c.

18. Shea W. The Abundant Life Bible Applifier. Daniel 7-12. Boise, Idaho, Oshawa, Ontario, Canada : Pacific Press Publishing Association, 1996. $236 \mathrm{c}$.

19. Stefanovic Z. Daniel: Wisdom to the Wise: Commentary on the Book of Daniel. Nampa, Idaho : Pacific Press Publishing Association, 2007. $480 \mathrm{c}$.

20. Stevenson K., Glerup M., Oden T. Ezekiel, Daniel (Ancient Christian Commentary on Scripture, OT Vol. 13). Downers Grove: IVP Academic, 2008. $396 \mathrm{c}$.

21. Walvoord J. Daniel: The Key to Prophetic Revelation. Chicago : Galaxie Software, 2008. 320 c.

\section{REFERENCES}

Bessonov, I. A. (2019). Daniel prophecies: origins, exegesis history, interpretation. Aletejja. [In Russian].

Volkoslavskij, R. (2008). Secrets of the Apocalypse. Historical commentary on the prophetic Books of Daniel and Revelation. Istochnik zhizni. [In Russian]. 
Dukan, Zh. (1995). The groaning of the earth. Study of the Book of the Prophet Daniel. Istochnik zhizni. [In Russian].

Ippolit, R. (2008). About Christ and Antichrist. Bibliopolis. [In Russian].

Svjatoj Efrem Sirin. Tvorenija. Vol. 6. (1995). Otchij dom. [In Russian].

Uirsbi, U. (2011). Commentary on the Old Testament. Vol. 2. Ezra - Malachi. Biblija dlja vseh. [In Russian].

Uolton, D., Mjet'juz, V. \& Chavales, M. (2003). Biblical cultural and historical commentary. Part 1: Old Testament. Mirt. [In Russian].

Andrews Bible Commentary (Old Testament). (2020). Berrien Springs: Andrews University Press.

Bracht, K., Du toit D. (2007). Die Geschichte der Daniel-Auslegung in Judentum, Christentum und Islam (Beihefte Zur Zeitschrift Fur die Alttestamentliche Wissenschaft). Berlin, New York: Walter de Gruyter.

Endresz, R. (2016). Daniel: A Survey of Patristic Exegesis. Phronema, 1(31), 123-152.

Froom, L. (1950). Prophetic Faith of Our Fathers. The Historical Development of Prophetic Interpretation. Vol. 1. Washington: Review and Herald.

Goldingay, J. (2002). Word Biblical Commentary, Vol. 30: Daniel. Dallas: Word.

Hill, R. Theodoret of Cyrus: Commentary on Daniel. Leiden, Boston: Brill, 2006. $367 \mathrm{c}$.

Holbrook, F. (1986). Symposium on Daniel (Daniel \& Revelation Committee Series). Washington: Biblical Research Institute.

MacArthur, J. (2000). Daniel: God's Control Over Rulers and Nations (MacArthur Bible Studies). Nashville: Thomas Nelson.

Pfandl, G. (2004). Daniel: The Seer of Babylon. Hagerstown: Review \& Herald Publishing.

Seventh-day Adventist Bible Commentary (Volume 4). (1977). Washington: Review and Herald Publishing Association.

Shea, W. (1996). The Abundant Life Bible Applifier. Daniel 7-12. Boise, Idaho, Oshawa, Ontario, Canada: Pacific Press Publishing Association. 
Stefanovic, Z. (2007). Daniel: Wisdom to the Wise: Commentary on the Book of Daniel. Nampa, Idaho: Pacific Press Publishing Association.

Stevenson, K., Glerup, M., Oden, T. (2008). Ezekiel, Daniel (Ancient Christian Commentary on Scripture, OT Volume 13). Downers Grove: IVP Academic.

Walvoord, J. (2008). Daniel: The Key to Prophetic Revelation. Chicago: Galaxie Software.

\title{
Ihor Kuryliak
}

Post-Graduate Student in Theology, The National Pedagogical Dragomanov University; Kyiv, Ukraine; e-mail: igor.kuryliak@gmail.com; ORCID: https://orcid.org/0000-0003-3955-1929

\section{Specifics of the interpretation of Ephrem the Syrian of eschatological images in Dan. 7}

\begin{abstract}
The article examines the peculiarities of the interpretation of Ephrem the Syrian of the seventh chapter of the apocalyptic book of the prophet Daniel. The interpretation of the theologian of eschatological images Dan. 7 is covered in the context of the analysis of hermeneutic principles. Ephrem has been found to interpret four beasts as Babylon, Media, Persia, and Greece. It is determined that this interpretation differs from the traditional interpretation of early Christian writers, who believed that the four kingdoms were Babylon, MedoPersia, Greece and Rome. The author of the article gives sound arguments that prove that the second kingdom is Medo-Persia, the third kingdom is Greece, and the fourth - Rome. It is presented that in the book of Daniel the Medes and Persians are presented as one kingdom. In the eighth chapter, the second and third beasts from the seventh chapter are directly identified as Medo-Persia and Greece. It is analyzed that the New Testament texts, historical data and details of prophetic eschatological images show that the fourth beast symbolizes the Roman Empire, not the Greek, as Ephrem claims. It is established that the interpretation of Ephrem does not find a biblical basis and therefore yields to the traditional interpretation. The analysis shows that the interpretation of Ephrem in the seventh chapter of the book of Daniel has the hermeneutic principles of the modern preterist school of interpretation. The theologian was
\end{abstract}


found to have interpreted the image of the little horn in Dan. 7 as Antiochus Epiphanes. The author of the article highlights the eight identifying features of the little horn, which are depicted in the seventh chapter. It is investigated that according to the representatives of the historical school the little horn symbolizes the papacy. Further consideration of this scientific issue is seen in the deep exegetical analysis of eschatological images in Dan. 7. We are convinced that this will allow us to better understand the apocalyptic symbols of the book of Daniel and contribute to its further comprehension.

Keywords: Book of Daniel, Ephrem the Syrian, Dan. 7, interpretation, apocalyptic, prophet Daniel, hermeneutics. 